SPY THRILLERS 


\section{INSIGHTS}

General Editor: Clive Bloom, Senior Lecturer in the Faculty of Humanities, Middlesex Polytechnic

Editorial Board: Clive Bloom, Brian Docherty, Gary Day, Lesley Bloom and Hazel Day

Insights brings to academics, students and general readers the very best contemporary criticism on neglected literary and cultural areas. It consists of anthologies, each containing original contributions by advanced scholars and experts. Each contribution concentrates on a study of a particular work, author or genre in its artistic, historical and cultural context.

Published titles

Clive Bloom (editor)

JACOBEAN POETRY AND PROSE: Rhetoric, Representation and the Popular Imagination

TWENTIETH-CENTURY SUSPENSE: The Thriller Comes of Age

SPY THRILLERS: From Buchan to le Carré

Clive Bloom, Brian Docherty, Jane Gibb and Keith Shand (editors)

NINETEENTH-CENTURY SUSPENSE: From Poe to Conan Doyle

Gary Day (editor)

READINGS IN POPULAR CULTURE; Trivial Pursuits?

Gary Day and Clive Bloom (editors)

PERSPECTIVES ON PORNOGRAPHY: Sexuality in Film and Literature

Brian Docherty (editor)

AMERICAN CRIME FICTION: Studies in the Genre

AMERICAN HORROR FICTION: From Brockden Brown to Stephen King

Rhys Garnett and R. J. Ellis (editors)

SCIENCE FICTION ROOTS AND BRANCHES: Contemporary Critical Approaches

Robert Giddings, Keith Selby and Chris Wensley

SCREENING THE NOVEL: The Theory and Practice of Literary

Dramatization

Mark Lilly (editor)

LESBIAN AND GAY WRITING: An Anthology of Critical Essays

Christopher Mulvey and John Simon (editors)

NEW YORK: City as Text

Jeffrey Walsh and James Aulich (editors)

VIETNAM IMAGES: War and Representation

Further titles in preparation 


\title{
Spy Thrillers
}

\section{From Buchan to le Carré}

\author{
Edited by \\ CLIVE BLOOM \\ Senior Lecturer in the Faculty of Humanities \\ Middlesex Polytechnic
}

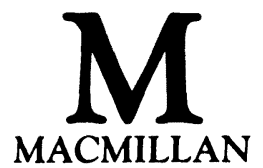


(C) The Lumière (Co-operative) Press Ltd 1990

All rights reserved. No reproduction, copy or transmission of this publication may be made without written permission.

No paragraph of this publication may be reproduced, copied or transmitted save with written permission or in accordance with the provisions of the Copyright, Designs and Patents Act 1988, or under the terms of any licence permitting limited copying issued by the Copyright Licensing Agency, 33-4 Alfred Place,

$$
\text { London WC1E 7DP. }
$$

Any person who does any unauthorised act in relation to this publication may be liable to criminal prosecution and civil claims for damages.

First published 1990

Published by

THE MACMILLAN PRESS LTD

Houndmills, Basingstoke, Hampshire RG21 2XS and London

Companies and representatives throughout the world

Typeset by Wessex Typesetters (Division of The Eastern Press Ltd) Frome, Somerset

British Library Cataloguing in Publicaton Data Spy thrillers: from Buchan to le Carré.-(Insights).

1. Spy fiction in English, to 1983-Critical studies

I. Bloom, Clive, 1953- II. Series $823^{\prime} .0872$

ISBN 978-0-333-52245-5

ISBN 978-1-349-21132-6 (eBook)

DOI $10.1007 / 978-1-349-21132-6$

\section{Series Standing Order}

If you would like to receive future titles in this series as they are published, you can make use of our standing order facility. To place a standing order please contact your bookseller or, in case of difficulty, write to us at the address below with your name and address and the name of the series. Please state with which title you wish to begin your standing order. (If you live outside the UK we may not have the rights for your area, in which case we will forward your order to the publisher concerned.)

Standing Order Service, Macmillan Distribution Ltd, Houndmills, Basingstoke, Hampshire, RG21 2XS, England. 
This one for Lesley - with love as always 


\section{Contents}

Preface and Acknowledgements

Notes on the Contributors

1 Introduction - The Spy Thriller: A Genre Under Cover? Clive Bloom

2 Cracked Bells and Really Intelligent Detonators:

Dislocation in Conrad's The Secret Agent

A. Robert Lee

3 The Adventure of Spying: Erskine Childers's The Riddle of The Sands

David Seed

4 The Hunter and the Hunted: The Suspense Novels of John Buchan

Dennis Butts

5 John Buchan: The Reader's Trap Miles Donald

6 The Story of an Encounter: Geoffrey Household's Rogue Male

Michael J. Hayes

7 Ian Fleming's Enigmas and Variations

Michael Woolf

8 The Great Game? The Spy Fiction of Len Deighton Dudley Jones

9 Are You Telling Me Lies David? The Work of John le Carré

Michael J. Hayes 
10 Reading John le Carré

Richard Bradbury

11 The Well-Wrought Structures of John le Carré's Early Fiction

David Seed

12 Professionalism and Popular Fiction: The Novels of Arthur Hailey and Frederick Forsyth

Dudley Jones

13 Spy Fiction and the Vietnam War

John Simons

185

Index

200 


\section{Preface and Acknowledgements}

This volume presents thirteen essays on the Spy Thriller in the twentieth century including a critical introduction to the subject. Each essay combines in a clear and understandable way formal, historical and aesthetic theory with sound practical criticism. Authors covered range from past masters such as Joseph Conrad and John Buchan to present masters such as Ian Fleming, Len Deighton and John le Carré, while subjects range widely from discussion of the formal characteristics of the genre to the conditions governing modern state surveillance and control of which the spy novel is not only a symptom but also a warning. The book, which combines a comprehensive range of literary approaches is the companion volume to Nineteenth-Century Suspense: From Poe to Conan Doyle, Twentieth-Century Suspense: The Thriller Comes of Age, Literature and Imperialism and American Crime Fiction: Studies in the Genre, all available in the Insights Series.

Thanks are due to Sarah Roberts-West who saw the value of such a book, to John Simons, Michael Hayes, Dudley Jones and Bob Lee for stepping into the breech, to Anne Rafique for her work on the manuscript and to Lesley for her patience and support.

C.B. 


\section{Notes on the Contributors}

Clive Bloom is a member of the Faculty of Humanities at Middlesex Polytechnic. He is the General Editor of the Insights Series and the author of books on literary criticism, Romanticism and popular culture.

Richard Bradbury teaches in the Department of English at the University of Warwick.

Dennis Butts recently retired from the English Department at Bulmershe College of Higher Education and is the Editor of Stories and Society: Children's Literature in its Social Context (forthcoming in the Insights Series).

Miles Donald is a novelist and literary critic whose work includes the thriller Diplomacy. He currently teaches in the School of English at Middlesex Polytechnic.

Michael J. Hayes teaches at the Lancashire Polytechnic. Besides American Crime Fiction, his research interests include Disraeli's early writings.

Dudley Jones lectures at Reading University. His research interests cover popular fiction and media studies.

A. Robert Lee is a Senior Lecturer in English and American Literature at the University of Kent in Canterbury. He is Editor of the Everyman Moby Dick and numerous collections in the Vision Critical Series.

David Seed lectures at Liverpool University, is the author of numerous articles and has recently published books on Thomas Pynchon and Joseph Heller.

John Simons lectures in English Literature at King Alfred's College, Winchester. He is the co-editor with Christopher Mulvey of New York: City as Text available as an Insights volume. 
Michael Woolf is a Director of the Council for International Educational Exchange in London. He has written numerous articles on cultural matters and regularly contributes to $\mathrm{BBC}$ programmes. 